\title{
THE MINIMAL EFFECT OF BODY MASS INDEX ON ICSI OUTCOME
}

\author{
Adel El Sayed, M.D. \\ Al-Azhar ART Unit, International Islamic Center for Population Studies and Research \\ (IICPSR) - Al-Azhar University, Cairo, Egypt
}

\section{ABSTRACT}

Objectives: To determine the effect of BMI on ICSI outcome.

Design: Retrospective study.

Setting: The ART Unit in the International Islamic Center for Population Studies and Research (IICPSR), Al-Azhar University.

Patients: The study used data collected from 550 who women had ICSI cycles at our center; the women were classilied according BMI as follow; $\left(<18.5 \mathrm{Kg} / \mathrm{m}^{2} ;>18.5-<25 \mathrm{Kg} / \mathrm{m}^{2} ;>25-30 \mathrm{Kg} / \mathrm{m}^{2} ;>30 \mathrm{Kg} / \mathrm{m}^{2}\right)$.

Main Outcome Measures: Duration of stimulation, consumption of gonadotropin, cycle cancellation, total oocyle retrieval, laboratory outcome and pregnancy outcome.

Results: The pregnancy outcome was $27 \%$ for $\mathrm{BMI}>18.5-<25 \mathrm{Kg} / \mathrm{m}^{2}$ - and $20 \%$ for $\mathrm{BMI}>25-<30 \mathrm{Kg} / \mathrm{m}^{2}$ and $\mathrm{BMI}$ $>30 \mathrm{Kg} / \mathrm{m}^{2}$, this difference was not statistically significant; also the number of $\mathrm{HMG}$ ampules were $34.1 \pm 13.1$ lor BMI $>30 \mathrm{Kg} / \mathrm{m}^{2}$ and $32.2 \pm 12.5$ for BMI $>25-<30 \mathrm{Kg} / \mathrm{m}^{2}$ and $25.1 \pm 11.9$ for BMI $18.5-<25 \mathrm{Kg} / \mathrm{m}^{2}$, this difference was statistically significant.

Conclusion: The overweight and obesity did not affect the ICSI outcome.

Key Words: BMI, Obesity, Ovarian Stimulation, ICSI outcome.

\section{INTRODUCTION}

Obesity is increasing rapidly among women allover the world, and more women in the fertile age become overweight and obese, besides all other problems, like hypertension, type 2 diabetes, coronary artery disease, stroke, gall bladder disease, sleep apnoae, endometrial carcinoma ${ }^{(1)}$. The women who are obese have higher rates of amenorrhoca and infertility, the fecundity decreases in obese women and some researcher advise weight reduction to improve fecundity ${ }^{(2)}$.

Obesity is defined as a BMI $>30 \mathrm{Kg} / \mathrm{m}^{2}-$. Normal weight is defined as BMI between 18.5 $\mathrm{Kg} / \mathrm{m}^{2}$ - and $24.9 \mathrm{Kg} / \mathrm{m}^{2}$-. Overweight is defined as $25.0 \mathrm{Kg} / \mathrm{m}^{2}-29.9 \mathrm{Kg} / \mathrm{m}^{2}$ - and extreme obesity is $>40$ $\mathrm{Kg} / \mathrm{m}^{2}$.

Many obese individuals of reproductive age attempt to conceive using ART. Some rescarchers examined the effect of BMI on IVF. They examined amount of follicles aspirated, egg number, number of embryos, peak estradiol, clinical pregnancy rate, miscarriage rate, implantation rate and incidence of ovarian hyperstimulation syndrome compared to controls with normal BMI; they found no significant effect on ICSI outcome $(3,4,5,6)$.

Other clinical studies, however, found significant effect of obesity on ICSI outcome in the form of low birth rate and impaired response to ovarian stimulation $(7,8,9,10,11,12,13)$ and some investigators advise weight reduction to improve outcome ${ }^{(14)}$.

The huge number of obese women seeking for assisted reproduction and controversial research related to this issue led to the performance of this work. The aim was to study the effect of BMI on the ICSI outcome. 


\section{PATIENTS \& METHODS}

A retrospective study was conducted to explore the impact of BMI on the ICSI outcome. The study used data collected from 550 women who had ICSI cycles at the assisted reproduction unit, International Islamic Center for Population Studies and Researches, Al-Azhar University, during the period from the first of July 2005 to the end of December 2006. The women above the age of 38 years and those with Basal FSH above $10 \mathrm{mIU} / \mathrm{L}$ were excluded from the study. The women were distributed by their BMI as flow, $<18.5 \mathrm{Kg} / \mathrm{m}^{2} ; 18.5-<25 \mathrm{Kg} / \mathrm{m}^{2}$; $>25-30 \mathrm{Kg} / \mathrm{m}^{2} ;>30 \mathrm{Kg} / \mathrm{m}^{2}$. The BMI was calculated as weight in $\mathrm{Kg}$ divided by height square in Meter square.

\section{ICSI Protocol:}

The ICSI embryo transfer protocol has been described in detail elsewhere (15); we used the long protocol; the down regulation started at day 21 of the cycle by injection of Decapeptyl $3.75 \mathrm{mg}$ single dose or Decapeptyl $0.1 \mathrm{mg}$ SC (Ferring, Germany) daily dose until time of HCG injection, after complete down regulation, HMG started in the form of Merional 75 IU (IBSA) or Menogon 75 IU (Ferring). The initial dose was 150 IU for women less than 30 years and 225 IU for women above the age of 30 years and those with high BMI. The main outcome was duration of stimulation, consumption of gonadotropin, cycle cancellation, total oocyte retrieval, laboratory outcome and pregnancy outcome.

Statistical Analysis:

The data were analyzed by using statistical analysis, software system (SAS Version 9.0; 2002). The clinical, laboratory, ovarian response and pregnancy outcome of the studied women were expressed as mean \pm SD for continuous variables and percent distribution for categorical variables and compared between different categories of body mass index, chi-square Fisher exact and $F$ (ANOVA) test were used as appropriate.

\section{RESULTS}

The study analysis included, 550 patients who participated in our ICSI program, according the distribution of BMI; Table (I), $<18.5 \mathrm{Kg} / \mathrm{m}^{2}$ ( $\mathrm{n}=10$, $2 \%) ;>18.5-<25 \mathrm{Kg} / \mathrm{m}^{2}(\mathrm{n}=80,14 \%) ;>25-<30$ $\mathrm{Kg} / \mathrm{m}^{2}(\mathrm{n}=290,52 \%) ; \geq 30 \mathrm{Kg} / \mathrm{m}^{2}(\mathrm{n}=179,32 \%)$, surprisingly most of our patients ( $85 \%$ of cases) were obese and overweight.

Table (II): No correlation was observed between different BMI and duration of HMG stimulation, but positive correlation was observed with total dose of HMG required for complete ovarian stimulation. Also no correlation was observed between various $\mathrm{BMl}$ categories and incidence of poor responder.

Table (III), Table (IV): No correlations were observed between various BMI and pereent of oocyte fertilization, number and quality of transferrec embryos.

Table (V): As regard pregnancy outcome, no correlation was observed between different BMI and pregnancy outcome; the pregnancy outcome was $20 \%$ for overweight and obese women and $27 \%$ for normal weight women.

\section{DISCUSSION}

We found that, overweight and obesity did not affect pregnancy outcome, oocyte fertilization, embryo quality and number of embryos available for transfer. Also, no correlation was observed with increased incidence of poor responders. On the other hand, a positive correlation was observed between increased BMI and number of HMG ampules required for ovarian stimulation.

These findings agree with observations reported by Lashen et al., 1999; Wang et al., 2000; Winter et 
al., 2002; Nicholes et al., 2003; Dokras et al., 2006) $(3,7,6,11,16)$. On the other hand, our findings contradict, the studies that correlate increased BMI with low birth rate during IVF (Fedorcsak et al., 2000; Wang et al., 2002; Fedorcsak et al., 2004) $(12,17,13)$

Fedorosak (2004) ${ }^{(13)}$, referred decreased birth rate in obese women to increased incidence of spontaneous abortion and not due to IVF procedures itself. Wang et al. (2002) ${ }^{(17)}$, explained increased incidence of spontaneous abortion during IVF procedures and referred such increase to endocrinological and biochemical mileu associated with obesity operating through the functional state, such as insulin resistance, which can create a hostile intrauterine environment for the oocyte or embryo. We observed an association, between increased BMI and increased HMG dose during ovarian stimulation. The correlation between obesity and increased HMG dose was not clear, because we used higher HMG dose in obese women, so the initial dose has to be fixed in order to refer increased dose to obesity.

Imani et al. (2002), found low threshold for HMG stimulation in the obese women and they advised increased initial dose of HMG in obese women in order to achieve proper ovarian response.

We did not find statistically significant differences in the fertilization rate, quality of embryo and number of embryos available for transfer; other studies however suggested that obesity and associated endocrine alterations may affect corpus luteum function (19,12), early embryo development $(20,21)$, trophoblastic function (22) and endometrial receptivity ${ }^{(23)}$.

In our IVF Center, we counselled the obese women about the impact of increased BMI on the ICSI outcome and we advised the patients to control their weight before starting ICSI program.

Although our study does not support a policy of excluding obese women from ICSI program based on poor ICSI outcome, we recommend counselling of obese women regarding the obstetric risks like; low birth weight ${ }^{(24)}$ and a higher rate of gestational DM and delivery by C.S. ${ }^{(25)}$, Stillbirth and neonatal death (26). On the other hand, the weight reduction was difficult to achieve in some women and time consuming particularly in old women, where age had definite deleterious effect on the ICSI outcome.

So, our recommendation is 10 advise women 10 control weight belore ICSI program to minimize the obstetric risk; we did not recommend weight reduction in older women because the age has marked deleterious effect on ICSI outcome.

\section{REFERENCES}

1. Hirsh J, Salans L, Aronne LJ: Obesity in principles and practice of endocrinology and metabolism, 3rd ed., Beckers, Ed (2001). Lippencon William and Wilkins, Philadelphia, pp. 1239-1240.

2. Gesinklow DG, Madehose RF, Longnecker MP: Obesity and time to pregnancy. Hum Reprod. (2007); 22(2) 414-420.

3. Lashen H, Ledger W, Lopez Bernal, Barlow D: Extremes of body mass do not adversely affect the outcome of superovulation and in vitro fertilization. Hum Reprod (1999); 14: 712-715.

4. Loh S, Wang JX, Matthews CD: The influence of body mass index, basal FSH, and age on the response to gonadotropin stimulation in non polycystic ovarian syndrome patients. Hum Reprod (2002); 17: 1207-1211.

5. Wittemer C, Ohi J, Bailly M, Battahar-Lebugle K and Nisand I: Does body mass index of infertile women have an impact on IVF procedures and outcome. J Assist Reprod Genet (2000); 17: 547-552.

6. Winter E, Wang JX, Davies M, Norman RJ: Early pregnancy loss following assisted reproductive technology treatment. Hum Reprod (2002); 17: 3220-3223.

7. Wang JX, Davies M, Norman RJ: Body mass and probability of pregnancy during assisted reproduction 
treatment. BMJ (2000); 32 [:1320-1335.

8. Farquhar CM, Gillet WR: Should high BM] exclude troument (2006); BJOG 113:1107-1113.

9. Carrel Jones KP, Peterson CM, Aoki V, Emery BR, Campibell BR (2001): Body mass index is inversely related to intrafollicular HCG concentration, embryo quality and IVF oulcome. Reprod Biomed online (2001); 3:109-111.

10. Mulders A, Liven JS, Jmani B, Eijkerman MG, Faucer BC: IVF outcome in anovalatory infertitity (WHO group 2) including polycystic ovary syndrome, following previous unsuccessfu] ovulation induction. Reprod Biomed Online (2003);7:50-59.

11. Nichols JE, Grane MM, Higdone HL, Miller PB, Boone WR: Extreme of body mass index reduce invitro ferlilizalion pregnancy rale. Fertil Steril (2003); 79:645-647.

12. Clarck AM, Thornleg B, Tomlinson L, Callelly C, Norman RJ: Weight loss in obese infertile women results in imprevement in reproductive outcome for all form of feltility trentment. Hum Reprod (1998); 13:1502-1505.

13. Fedoresak P, Storeng R, Dale PO, Tanbo $T$, Abyholm $\mathrm{T}$ : Obesity is associated with early pregnancy loss after IVF or ICSI. Acta Obstet Gynecol Seind. (2000) ; 79:43-48.

14. Fedoresake P, Dale OP, Stoteng R, Extezcial G, Bjercke $S$, Oldeneid $N$, Omland $A K$, Abyhold $T$, Tambo $T$ : Impact of overweight and underweight on assisted reproduction Ireatment. Hum Reprod. (2004): [9(1]) : 2523-2528.

15. Lockwood GM. Pirkerton SM, Barlow DH: A prospective randomized single flind comparalive trial of naliartiu acelate with buserlin in long protocol gonadotropin-relensing trormonc analogue costrolled in vitro lertilizalion cycles. Hum Reprod. (1995); 10: $293-298$.

16. Anuja Dokras, Lindscy Baredzink, Jill Blaine, Cruigo syrop, Bradley J, Van Vorrlxis, Amy Sparks: Olese and morbidly obese women have higher cancellation rate and poor obstetric outcome after in vitro lierilization. Obst. Gynceol. (2006); 188:61-69.
17- Wang JX, Davies M, Norman RJ: Obesity increase the risk of spontaneous abortion during infertility treatment. Obese Res (2002); 10:551-554.

18. Imani B, Eijkemans MJ, Fassen GA, Bouchard P. Giudice LC, Fauser BC: Prediction of the individual follicle stimulating hormone threshold for gonadotropin induction of ovulation in normogonadolropic anovulatory infertility: an approach to increase safety and efficiency. Fertil Sicril. (2002); 77:83-90.

19. Sherman BM, Korenman SG: Measurement of serum LH, FSH, Estradicl and Progesterone in disorders of the humar menstrual cycle: the inadequate lutcal phase. J Clin Endocrinol Metab. (1974): 39:145-149.

20. Kawamura K, Sato N, Fukuda J, Kodama H (2002): Leptin promotes the development of meuse proimplantation embryo in vitro. Endocrinol. (2002); 143:1922-1931.

21. Fodotrsak [', Storeng R: Effeel of leptin and Inulamia inbibitory fastor on preimplarialion developmenl. Hum Reprod. (2003); 69, 153 I-1533.

22. Castellucci M, DSE Malteis R, Meissn A, Cancello R, Mansurro V, Islami D, Sarzani R, Marzioni D, Cinti S, Bishol P: Leptin modulatc extracellular matrix molecules and melallo-proteinase, possible, implicat-ion for tropho-blastic invasion. Hum Reprod (2000); 6:951-958.

23. Hiller SG: Controlled ovarian stimulation in women. J Reprod Fertil. (2000); 120:201-210.

24. Van der Spug. Steer PJ, Mccusker M: Oulcome of pregnancy in underweight women after spontancous and induced ovulation. BMJ Med J (1985); 296: 262-467.

25. Ramos GA, Caughey AB: The interrelationship between ethricily and obesity on obstetric outcome. American Joumal of Obstetrics and Gynecology (2005); 139(3): 1089-1093).

26. Kristemsen J: Pregnancy weight and the risk of stillbirth and neonatal death. BIJOG (2005); 112 (4):403-408. 
Table I : Clinical Data of Women According to BMI.

\begin{tabular}{|c|c|c|c|c|c|}
\hline \multirow[b]{2}{*}{ Variable } & \multicolumn{4}{|c|}{ BMI $\mathrm{Kg} / \mathrm{m}^{2}$} & \multirow{2}{*}{ P. Value } \\
\hline & $\begin{array}{c}<18.5 \\
(n=10)\end{array}$ & $\begin{array}{c}18.5 \cdot<25 \\
(n=80)\end{array}$ & $\begin{array}{l}25-<30 \\
(\mathrm{n}=290)\end{array}$ & $\begin{array}{c}\geq 30 \\
(n=176)\end{array}$ & \\
\hline Age in years (mean $\pm S D)$ & $28.5 \pm 5.2$ & $27.5 \pm 4.8$ & $30.2 \pm 5.7$ & $32.8 \pm 3.5$ & $0.001^{*}$ \\
\hline $\begin{array}{l}\text { Duration of infertility in years } \\
\text { (mean } \pm S D \text { ) }\end{array}$ & $7.4 \pm 5.3$ & $5.9 \pm 4.4$ & $7.7 \pm 4.9$ & $8.9 \pm 5.0$ & $0.002^{* *}$ \\
\hline $\begin{array}{l}\text { Main cause of infertility } \\
\text { Male factor } \\
\text { Female factor }\end{array}$ & $\begin{array}{l}2(20.0) \\
8(80.0)\end{array}$ & $\begin{array}{l}36(55.0) \\
44(45.0)\end{array}$ & $\begin{array}{l}138(52.0) \\
150(48 \%)\end{array}$ & $\begin{array}{l}60(66 \%) \\
115(44 \%)\end{array}$ & 0.01 \\
\hline $\begin{array}{l}\text { Age (Categories) } \\
<24 \mathrm{yrs} \\
24-<30 \mathrm{yrs} \\
30-<36 \mathrm{yrs} \\
>=36 \mathrm{yrs}\end{array}$ & $\begin{array}{l}1(10.0) \\
6(60.0) \\
2(20.0) \\
1(10.0) \\
\end{array}$ & $\begin{array}{c}18(22 \%) \\
35(44.0) \\
23(29.0) \\
4(5.0) \\
\end{array}$ & $\begin{array}{l}34(12.0) \\
100(34.0) \\
102(35.0) \\
52(19.0)\end{array}$ & $\begin{array}{c}7(4.0) \\
48(27.0) \\
58(33.0) \\
63(36.0) \\
\end{array}$ & $<0.0001$ \\
\hline $\begin{array}{l}\text { Number of ICSI cycle } \\
\text { One cycle } \\
\text { More than one cycle }\end{array}$ & $\begin{array}{l}9(90.0) \\
1(10.0)\end{array}$ & $\begin{array}{l}68(85.0) \\
12(15.0)\end{array}$ & $\begin{array}{l}225(78.0) \\
65(22.0)\end{array}$ & $\begin{array}{l}128(73.0) \\
48(27.0)\end{array}$ & 0.12 \\
\hline
\end{tabular}

* Significance

Table II: Ovarian Response According to BMI.

\begin{tabular}{|c|c|c|c|c|c|}
\hline \multirow{2}{*}{ Variable } & \multicolumn{4}{|c|}{ BMI $\mathrm{Kg} / \mathrm{m}^{2}$} & \multirow{2}{*}{ P. Value } \\
\hline & $\begin{array}{c}<18.5 \\
(n=10)\end{array}$ & $\begin{array}{c}18.5-<25 \\
(n=80)\end{array}$ & $\begin{array}{l}25-<30 \\
(n=290)\end{array}$ & $\begin{aligned} & \geq 30 \\
(n & =176)\end{aligned}$ & \\
\hline $\begin{array}{l}\text { Duration of HMG treatment } \\
\text { (mean } \pm S D \text { ) }\end{array}$ & $13.2 \pm 2.3$ & $13.3 \pm 2.5$ & $16.9 \pm 5.1$ & $13.3 \pm 2.3$ & 0.77 \\
\hline $\begin{array}{l}\text { Tolal HMG dose } \\
\text { (mean } \pm \text { SD) }\end{array}$ & $29.4 \pm 12.0$ & $25.1 \pm 11.9$ & $32.2 \pm 12.5$ & $34.1 \pm 13.2$ & $<0.0001^{*}$ \\
\hline Poor Responder & $0(0.0)$ & $12(15.0)$ & $25(9.0)$ & $23(13.0)$ & 0.80 \\
\hline
\end{tabular}

* Significance 
Table III: Fertilization Percent According to BMI.

\begin{tabular}{|c|c|c|c|c|c|}
\hline \multirow[b]{2}{*}{ Variable } & \multicolumn{4}{|c|}{$\mathrm{BMI} \mathrm{Kg} / \mathrm{m}^{2}$} & \multirow{2}{*}{ P. Value } \\
\hline & $\begin{array}{l}<18.5 \\
(n=10)\end{array}$ & $\begin{array}{c}18.5-<25 \\
(n=80)\end{array}$ & $\begin{array}{l}25-<30 \\
(\mathrm{n}=290)\end{array}$ & $\begin{array}{c}\geq 30 \\
(n=176)\end{array}$ & \\
\hline$\%$ of ferlilization & & & & & \\
\hline Positive & $10(100.0)$ & $66(97 \%)$ & $254(95 \%)$ & $149(97.0)$ & 0.77 \\
\hline Negative & $0(0.0)$ & $2(3.0)$ & $11(5.0)$ & $4(3.0)$ & \\
\hline $\begin{array}{l}\text { Mean \% fertilization of injected } \\
\text { oucylc }\end{array}$ & $81.0 \pm 25.0$ & $71.0 \pm 23.0$ & $74.0 \pm 25.0$ & $77.0 \pm 23.0$ & 0.41 \\
\hline
\end{tabular}

Table IV: Laboratory Data According to BMI .

\begin{tabular}{|c|c|c|c|c|c|}
\hline \multirow[b]{2}{*}{ Variable } & \multicolumn{4}{|c|}{ BMI $\mathrm{Kg} / \mathrm{m}^{2}$} & \multirow{2}{*}{ P. Value } \\
\hline & $\begin{array}{c}<18.5 \\
(n=10)\end{array}$ & $\begin{array}{c}18.5-<25 \\
(n=80)\end{array}$ & $\begin{array}{l}25-<30 \\
(\mathrm{n}=290)\end{array}$ & $\begin{array}{c}\geq 30 \\
(\mathrm{n}=176)\end{array}$ & \\
\hline Mean number of embryo transfer & $3.0 \pm 0.9$ & $2.8 \pm 0.9$ & $2.8 \pm 1.0$ & $2.9 \pm 1.1$ & 0.75 \\
\hline mean number of embryo (Grade $A$ ) & $4.0 \pm 2.6$ & $3.6 \pm 2.3$ & $3.6 \pm 2.3$ & $3.4 \pm 2.4$ & 0.54 \\
\hline Mcan number of embryo (Grade B) & $3.0 \pm 2.4$ & $1.8 \pm 1.2$ & $2.2 \pm 1.6$ & $1.8 \pm 1.2$ & 0.16 \\
\hline $\begin{array}{l}\text { Meall number of cells of embryo } \\
\text { transfer }\end{array}$ & $5.6 \pm 4.3$ & $4.3 \pm 2.9$ & $4.6 \pm 3.2$ & $4.1 \pm 2.9$ & 0.30 \\
\hline
\end{tabular}

Table V : ICSI Outcome According to BMI.

\begin{tabular}{|c|c|c|c|c|c|c|}
\hline \multirow{2}{*}{ Variable } & \multicolumn{4}{|c|}{ Clinical Pregnancy } & \multirow{2}{*}{ Total } & \multirow{2}{*}{ P. Value } \\
\hline & No. & $\%$ & No. & $\%$ & & \\
\hline$<18.5 \mathrm{Kg} / \mathrm{m} 2$ & 2 & 20.0 & 8 & 80.0 & 10 & \\
\hline $18.5-<25 \mathrm{Kg} / \mathrm{m} 2$ & 18 & 27.0 & 48 & 73.0 & 66 & \\
\hline $25-<30 \mathrm{Kg} / \mathrm{m} 2$ & 51 & 20.0 & 203 & 80.0 & 254 & \\
\hline$\geq 30-\mathrm{Kg} / \mathrm{m} 2$ & 30 & 20.0 & 119 & 80.0 & 149 & \\
\hline Total & 101 & 21.0 & 378 & 78.9 & 479 & 0.60 \\
\hline
\end{tabular}

